\title{
Body mass index and cholesterol level predict surgical outcome in patients with hepatocellular carcinoma in Taiwan - a cohort study
}

\author{
Ya-Ling Lee ${ }^{1,2,3, *}$, Wan-Chun $\mathrm{Li}^{3,4,5, *}$, Tung-Hu Tsai, ${ }^{5,6}$ Hin-Yu Chiang ${ }^{4}$ and Chin- \\ Tsung Ting ${ }^{6,7}$ \\ ${ }^{1}$ Institute of Public Health and Community Medicine Research Center, National Yang-Ming University, Taipei, Taiwan \\ 2 Department of Dentistry, Taipei City Hospital, Taipei, Taiwan \\ ${ }^{3}$ Department of Dentistry, School of Dentistry, National Yang-Ming University, Taipei, Taiwan \\ ${ }^{4}$ Institute of Oral Biology, School of Dentistry, National Yang-Ming University, Taipei, Taiwan \\ ${ }^{5}$ Department of Education and Research, Taipei City Hospital, Taipei, Taiwan \\ ${ }^{6}$ Institute of Traditional Medicine, School of Medicine, National Yang-Ming University, Taipei, Taiwan \\ ${ }^{7}$ Division of Gastrointestinal Surgery, Department of Surgery, Ren-Ai Branch, Taipei City Hospital, Taipei, Taiwan \\ * These authors have contributed equally to this work \\ Correspondence to: Chin-Tsung Ting, email: DAB74@tpech.gov.tw \\ Keywords: hepatocellular carcinoma, body mass index, serum cholesterol level, curative surgical resection, prognostic indicator \\ Received: September 21, $2015 \quad$ Accepted: March 06, $2016 \quad$ Published: March 24, 2016
}

\section{ABSTRACT}

Curative surgical resection (CSR) remains the most effective therapeutic intervention for patients with hepatocellular carcinoma (HCC); however, frequent postsurgical recurrence leads to high cancer related mortality. This study aimed to clarify the role of body mass index (BMI) and serum cholesterol level in predicting postsurgical outcomes in HCC patients after CSR. A total of 484 HCC patients including 213 $\mathrm{BMI}^{\text {high }}$ and $271 \mathrm{BMI}^{\text {low }}$ patients were included. Overall survival (OS) and recurrencefree survival (RFS) rates were examined in patients with differential BMI and serum cholesterol level. The analysis showed that significant different 1-, 3- and 5-year cumulative OS rates $(P$-value $=0.015)$ and RFS rate $(P$-value $=0.010)$ between $B M I^{\text {low }}$ and $B M I^{\text {high }}$ patients. Further analysis in groups with differential serum cholesterol levels among $\mathrm{BMI}^{\mathrm{low}}$ and $\mathrm{BMI}^{\text {high }}$ patients indicated that the $\mathrm{BMI}^{\text {low }} / \mathrm{Chol}^{\text {low }}$ patients exhibited the significant lower cumulative OS and RFS rates in comparison with the remaining subjects ( $P$-value $=0.007$ and 0.039 for $O S$ and RFS rates, respectively). In conclusion, the coexistence of low BMI and low serum cholesterol level could serve as prognostic factors to predict post-operative outcomes in HCC patients undergoing surgical hepatectomy.

\section{INTRODUCTION}

Hepatocellular carcinoma (HCC) is the fifth most common cancer and the third leading cause of cancerrelated deaths worldwide [1]. Hepatic resection remains one of the most common, effective, and widely accepted therapeutic interventions for patients with $\mathrm{HCC}[2$, 3]. However, frequent recurrence of HCC in patients undergoing surgical treatment procedure, such as curative hepatic resection, still results in high cancer related mortality. A recent study has shown that a number of risk factors, such as preoperative serological C-reactive protein (CRP) level, correlated with cancer recurrence in patients with HCC after hepatic resection, revealing the possibility to predict surgical outcome by preoperative clinical physiological parameters [4]. To simplify clinical procedure, the candidate index to predict surgical outcome would need to be common and easy to interpret. While body mass index (BMI) is the most easily accessible information from routine checkouts, testing the correlation of patients' BMI and HCC prognosis is of great interest. Although obesity has been recognized as a potential 
life-threatening epidemical risk factor globally, previous epidemiological evidence for the association of BMI and primary $\mathrm{HCC}$ incidence and correlation of obesity and HCC prognosis remains inconclusive $[5,6]$. It was shown that obesity is associated with an increased incidence of multiple types of cancers as well as an increased perioperative morbidity and mortality in patients undergoing major surgical procedures [7]. Several studies have shown that greater HCC prevalence and patient mortality are associated with a high BMI whereas poorer perioperative outcomes with hepatectomy was observed in HCC subjects with greater BMI [8-12]. In contrast, other groups demonstrated that overweight (BMI $\geq 25$ ) was not a risk factor for surgical outcomes after hepatic resection in patients with primary HCC [13]. The reasons behind these conflicting data might possibly be due to the discordant classification of obesity status among different studies and lack of large sample sized prospective cohortbased investigations. In addition, the fact that other confounding molecular cues, including elevated levels of insulin-like growth factors [14], leptin [15], hormones [16] and cytokines [17] were not adjusted in studies, could also result in the divergent interpretations for prognosis after hepatectomy between lean and obese subjects. With a causal link between BMI and total cholesterol level in many cancers, it was interestingly found an inverse correlation between preoperative total cholesterol levels and clinical postoperative outcomes of $\mathrm{HCC}$ patients in several studies [18-20]. Further examination in these studies suggested that poorer surgical outcome in patients with lower preoperative total cholesterol level and BMI might be caused by long-term liver dysfunction and malnutrition implying the potential role of lipid composition for determination of operative outcomes in

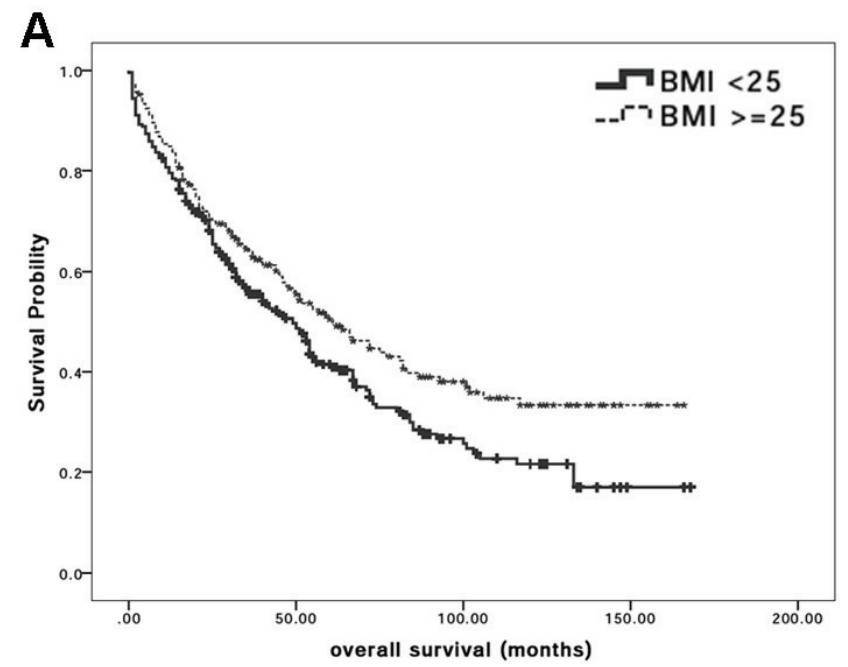

HCC patients.

Taken together, we hypothesized herein that preoperative BMI and serological cholesterol level could possibly predict long-term outcome in HCC patients undergoing curative treatment. To test this hypothesis, a prospective cohort-based database of patients with primary HCC undergoing hepatic resection surgery from 2000 to 2010 was retrospectively examined. While BMI is considered as a good index for the prediction of medically significant obesity according to National Institutes of Health Consensus Development Conference (NIHCDC) [21], the obesity associated confounding factors including lipid profile and tumor stage were adjusted to better define the correlation between BMI / total cholesterol level and postoperative outcomes in $\mathrm{HCC}$ patients.

\section{RESULTS}

\section{Differential preoperative clinical information of HCC patients with different BMI}

Using 25 as a cutoff value, $271 \mathrm{HCC}$ patients $(56 \%)$ were classified as $\mathrm{BMI}^{\text {low }}$ and $213 \mathrm{HCC}$ patients (44\%) were in the $\mathrm{BMI}^{\text {high }}$ group. The demographic data and preoperative laboratory examination of these two groups are summarized in Table 1. Among all readouts, there is no significant difference between two groups for age, gender, blood glucose and the preoperative liver function parameters including serum AFP, serum albumin, total bilirubin concentration, AST activity. The tumor characteristics such as grades of tumor size, number, Child-Pugh stage, TNM classification, differentiation

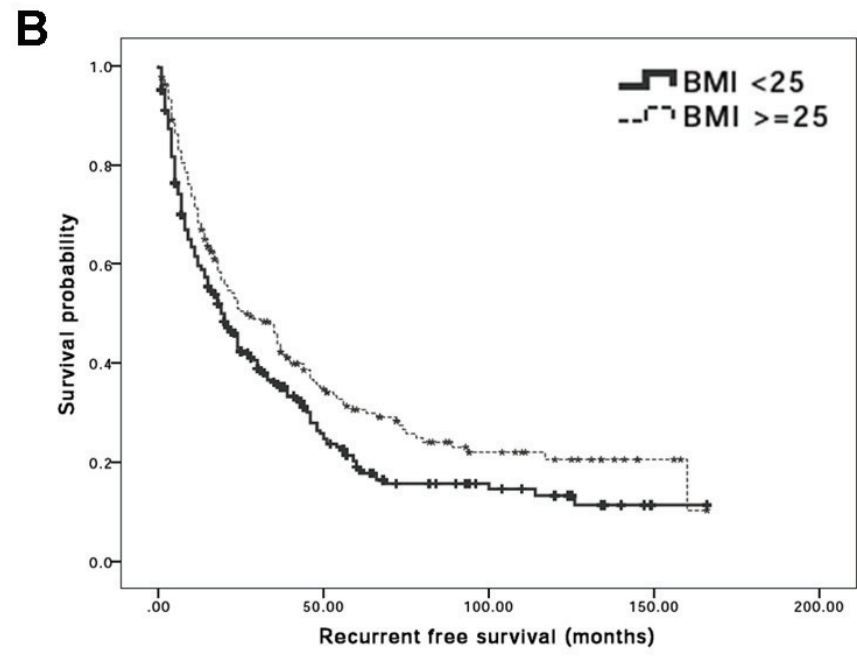

Figure 1: BMI is significantly correlated with surgical outcome after curative hepatectomy. A. Kaplan-Meier survival curves for overall survival in HCC patients who received hepatectomy according to BMI classification. The cumulative overall survival rates were significantly lower in the $\mathrm{BMI}^{\text {low }}$ group patients than $\mathrm{BMI}{ }^{\text {high }}$ group patients (log-rank test; $p=0.015$ ); B. Kaplan-Meier survival curves for recurrence-free survival in HCC patients who received hepatectomy according to BMI classification. The cumulative recurrencefree survival rates were significantly lower in $\mathrm{BMI}^{\text {low }}$ than $\mathrm{BMI}^{\text {high }}$ group $(\log$-rank test; $P$-value $=0.010)$. 
Table 1: Demographic and laboratory data of participants prior to hepatic resection surgery.

\begin{tabular}{|c|c|c|c|c|}
\hline Characteristics & $\mathrm{BMI}^{\text {low }}(<25)$ & BMI $^{\text {high }}(\geq 25)$ & Total () & P-value \\
\hline Age (years) & 61.5 & 61.8 & $61.6(484)$ & $0.049^{*}$ \\
\hline$<57$ & 88 & 68 & 156 & \\
\hline$\geq 57$ & 183 & 145 & 328 & 0.896 \\
\hline Gender & & & $\underline{484}$ & \\
\hline Male & 202 & 161 & $\overline{363}$ & \\
\hline Female & 69 & 52 & 121 & 0.792 \\
\hline DM status & & & 484 & \\
\hline Non-DM & 209 & 142 & 351 & \\
\hline DM & 62 & 71 & 133 & $0.011^{*}$ \\
\hline Hepatitis & & & 484 & \\
\hline B & 193 & 158 & 351 & \\
\hline C & 78 & 55 & 133 & 0.469 \\
\hline Serum AFP ( $\mu \mathrm{g} / \mathrm{L})$ & 4259.7 & 4997.2 & $4589.8(467)$ & 0.818 \\
\hline$\leqslant 400$ & 202 & 167 & 369 & \\
\hline$>400$ & 56 & 42 & 98 & 0.671 \\
\hline Total bilirubin (mg/dl) & 1 & 1.23 & $1.1(479)$ & 0.263 \\
\hline$<1.2$ & 199 & 153 & 352 & \\
\hline$\geq 1.2$ & 69 & 58 & 127 & 0.668 \\
\hline Serum albumin (mg/dl) & 3.87 & 3.95 & $3.9(\underline{475})$ & 0.062 \\
\hline$<3.5$ & 46 & 31 & 77 & \\
\hline$\geq 3.5$ & 219 & 179 & 398 & 0.446 \\
\hline Blood glucose (mg/dl) & 107.7 & 119.8 & $113.1(476)$ & 0.142 \\
\hline$<126$ & 220 & 167 & 387 & \\
\hline$\geq 126$ & 47 & 42 & 89 & 0.489 \\
\hline AST $(I U / m L)$ & 58.9 & 51.4 & $55.6(481)$ & 0.084 \\
\hline$<40$ & 127 & 108 & 235 & \\
\hline$\geq 40$ & 242 & 104 & 246 & 0.416 \\
\hline Total cholesterol (mg/dl) & 163.9 & 168.9 & $166.1(394)$ & 0.149 \\
\hline$<200$ & 191 & 135 & 326 & \\
\hline$\geq 200$ & 30 & 38 & 68 & $0.029^{*}$ \\
\hline Child stage & & & 437 & \\
\hline A & 206 & 172 & 378 & \\
\hline B & 37 & 20 & 57 & \\
\hline C & 2 & 0 & 2 & 0.153 \\
\hline TNM stage & & & $\underline{437}$ & \\
\hline 1 & 66 & 57 & 123 & \\
\hline ॥ & 104 & 88 & 192 & \\
\hline III & 45 & 40 & 85 & \\
\hline IV & 27 & 10 & 37 & 0.165 \\
\hline Differentiation & & & 430 & \\
\hline Well & 17 & 11 & 35 & \\
\hline Moderate & 136 & 93 & 246 & \\
\hline Poor & 86 & 87 & 199 & 0.131 \\
\hline Size $(\mathrm{cm})$ & & & 484 & \\
\hline$<5$ & 182 & 154 & 336 & \\
\hline$\geq 5$ & 89 & 59 & 148 & 0.223 \\
\hline Number & & & 484 & \\
\hline Single & 228 & 180 & 408 & \\
\hline Multiple & 43 & 33 & 76 & 0.911 \\
\hline Vascular invasion & & & 379 & \\
\hline Positive & 143 & 110 & $\overline{253}$ & \\
\hline Negative & 67 & 59 & 126 & 0.537 \\
\hline
\end{tabular}

The results indicated that the obese patients have a high diabetic incidence and high cholesterol levels as others factor showed no significant difference between $\mathrm{BMI}^{\mathrm{high}}$ and $\mathrm{BMI}^{\mathrm{low}}$ groups. $*: P$-value $<0.05$. 
Table 2: Exploration of potential risk factors for post-operative (A) HCC recurrence and (B) OS rate according to univariate and multivariate proportional hazard models.

\begin{tabular}{|c|c|c|c|c|}
\hline \multirow{2}{*}{ Variable } & \multicolumn{2}{|c|}{ Univariate Cox-regression } & \multicolumn{2}{|c|}{ Multivariate Cox-regression } \\
\hline & $\mathrm{HR}(95 \% \mathrm{Cl})$ & P-value & $\mathrm{HR}(95 \% \mathrm{Cl})$ & P-value \\
\hline Age (57yrs) & $1.26(1.01 \sim 1.58)$ & $0.046^{*}$ & $1.2(0.91 \sim 1.58)$ & 0.19 \\
\hline Gender (Female) & $0.78(0.04 \sim 0.98)$ & $0.036^{*}$ & $1.9(0.68 \sim 1.2)$ & 0.476 \\
\hline $\begin{array}{c}\text { Obesity } \\
\left(\mathrm{BM} \mid>25 \mathrm{Kg} / \mathrm{m}^{2}\right)\end{array}$ & $0.76(0.61 \sim 1.94)$ & $0.011^{*}$ & $0.76(0.59 \sim 0.98)$ & $0.032^{*}$ \\
\hline Diabetes (Y/N) & $0.82(0.81 \sim 1.3)$ & 0.815 & - & - \\
\hline Etiology (HCV/others) & $1.23(0.98 \sim 1.55)$ & 0.072 & - & - \\
\hline $\begin{array}{c}\text { Serum AST value } \\
(>401 \mathrm{U} / \mathrm{L})\end{array}$ & $1.52(1.23 \sim 1.88)$ & $<0.001^{*}$ & $1.27(0.98 \sim 1.65)$ & 0.067 \\
\hline Sugar(>126mg/dl) & $1.26(0.97 \sim 1.64)$ & 0.088 & & \\
\hline $\begin{array}{c}\text { Serum } \\
\text { albumin( }>3.5 \mathrm{mg} / \mathrm{dl})\end{array}$ & $0.49(0.37 \sim 0.64)$ & $<0.001^{*}$ & $0.46(0.31 \sim 0.68)$ & $<0.001^{*}$ \\
\hline $\begin{array}{c}\text { Serum } \\
\text { bilirubin(>1.2mg/dl) }\end{array}$ & $1.36(1.07 \sim 1.72)$ & $0.012^{*}$ & $1.14(0.86 \sim 1.51)$ & 0.369 \\
\hline $\begin{array}{c}\text { Serum cholesterol } \\
\text { (>200 } \mathrm{mg} / \mathrm{dl})\end{array}$ & $0.95(0.7 \sim 1.31)$ & 0.772 & - & - \\
\hline $\begin{array}{l}\text { Serum triglyceride } \\
(>200 \mathrm{mg} / \mathrm{dl})\end{array}$ & $0.85(0.49 \sim 1.48)$ & 0.566 & - & - \\
\hline $\begin{array}{c}\text { Serum AFP value } \\
(>400 \mathrm{ng} / \mathrm{ml})\end{array}$ & $1.64(1.28 \sim 2.11)$ & $<0.001^{*}$ & $1.5(1.1 \sim 2.05)$ & $0.01^{*}$ \\
\hline $\begin{array}{l}\text { Child-Pugh grade (B } \\
\text { or C) }\end{array}$ & $2(1.5 \sim 2.66)$ & $<0.001^{*}$ & $1.21(0.82 \sim 1.79)$ & 0.346 \\
\hline TNM stage & $1.43(1.26 \sim 1.61)$ & $<0.001^{*}$ & $1.32(1.07 \sim 1.64)$ & $0.011^{*}$ \\
\hline Diff. degree (Poor) & $1.39(1.16 \sim 1.68)$ & $<0.001^{*}$ & $1.37(1.07 \sim 1.75)$ & $0.012^{*}$ \\
\hline Tumor size $(>5 \mathrm{~cm})$ & $1.9(1.52 \sim 2.37)$ & $<0.001^{*}$ & $1.31(0.93 \sim 1.84)$ & 0.124 \\
\hline $\begin{array}{c}\text { Tumor number } \\
\text { (multiplicity) }\end{array}$ & $1.32(1.01 \sim 1.73)$ & $0.048^{*}$ & $0.99(0.71 \sim 1.37)$ & 0.933 \\
\hline $\begin{array}{c}\text { Vascular invasion } \\
\text { (N/Y) }\end{array}$ & $0.74(0.58 \sim 0.95)$ & $0.02^{*}$ & $1.31(0.9 \sim 1.9)$ & 0.165 \\
\hline
\end{tabular}

\begin{tabular}{|c|c|c|c|c|}
\hline \multirow{2}{*}{ Variable } & \multicolumn{2}{|c|}{ Univariate Cox-regression } & \multicolumn{2}{|c|}{ Multivariate Cox-regression } \\
\hline & HR(95\% Cl) & P-value & $\mathrm{HR}(95 \% \mathrm{Cl})$ & P-value \\
\hline Age (57yrs) & $1.29(1.01 \sim 1.66)$ & $0.046^{*}$ & $1.25(0.93 \sim 1.68)$ & 0.133 \\
\hline Gender (Female) & $0.76(0.61 \sim 1.01)$ & 0.058 & - & - \\
\hline $\begin{array}{c}\text { Obesity } \\
\left(\mathrm{BM} \mid>25 \mathrm{Kg} / \mathrm{m}^{2}\right)\end{array}$ & $0.75(0.59 \sim 0.95)$ & $0.016^{\star}$ & $0.73(0.55 \sim 0.97)$ & $0.031^{\star}$ \\
\hline Diabetes (Y/N) & $0.93(0.72 \sim 1.21)$ & 0.596 & $\cdot$ & - \\
\hline $\begin{array}{c}\text { Etiology ( } \\
\text { HCV/others) }\end{array}$ & $1.15(0.9 \sim 1.47)$ & 0.273 & - & - \\
\hline $\begin{array}{c}\text { Serum AST } \\
\text { value( }>401 U / L)\end{array}$ & $1.61(1.27 \sim 2.03)$ & $<0.001^{*}$ & $1.26(0.95 \sim 1.68)$ & 0.11 \\
\hline Sugar(>126mg/dl) & $1.06(0.78 \sim 1.43)$ & 0.714 & - & $\cdot$ \\
\hline $\begin{array}{c}\text { Serum } \\
\text { albumin( }>3.5 \mathrm{mg} / \mathrm{dl})\end{array}$ & $0.43(0.32 \sim 0.57)$ & $<0.001^{*}$ & $0.53(0.35 \sim 0.81)$ & $0.003^{*}$ \\
\hline $\begin{array}{c}\text { Serum } \\
\text { bilirubin( }>1.2 \mathrm{mg} / \mathrm{dl})\end{array}$ & $1.61(1.25 \sim 2.07)$ & $<0.001^{*}$ & $1.21(0.9 \sim 1.64)$ & 0.21 \\
\hline $\begin{array}{l}\text { Serum cholesterol } \\
(>200 \mathrm{mg} / \mathrm{dl})\end{array}$ & $0.85(0.6 \sim 1.21)$ & 0.366 & - & - \\
\hline $\begin{array}{l}\text { Serum triglyceride } \\
(>200 \mathrm{mg} / \mathrm{dl})\end{array}$ & $0.64(0.32 \sim 1.3)$ & 0.216 & - & $\cdot$ \\
\hline $\begin{array}{c}\text { Serum AFP } \\
\text { value( }>400 \mathrm{ng} / \mathrm{ml})\end{array}$ & $1.86(1.43 \sim 2.43)$ & $<0.001^{*}$ & $1.78(1.2 \sim 2.46)$ & $<0.001^{*}$ \\
\hline $\begin{array}{l}\text { Child-Pugh grade (B } \\
\text { or C) }\end{array}$ & $2.63(1.98 \sim 3.51)$ & $<0.001^{*}$ & $1.71(1.13 \sim 2.59)$ & $0.011^{*}$ \\
\hline TNM stage & $1.51(1.32 \sim 1.72)$ & $<0.001^{*}$ & $1.29(1.02 \sim 1.62)$ & $0.033^{*}$ \\
\hline Diff. degree (Poor) & $1.34(1.09 \sim 1.65$ & $<0.005^{\star}$ & $1.15(0.89 \sim 1.49)$ & 0.284 \\
\hline Tumor size $(>5 \mathrm{~cm})$ & $2.1(1.65 \sim 2.66)$ & $<0.001^{*}$ & $1.47(1.01 \sim 2.14)$ & $0.045^{\star}$ \\
\hline $\begin{array}{c}\text { Tumor number } \\
\text { (multiplicity) }\end{array}$ & $1.13(0.84 \sim 1.52)$ & 0.434 & - & - \\
\hline $\begin{array}{c}\text { Vascular invasion } \\
(\mathrm{N} / \mathrm{Y})\end{array}$ & $0.7(0.53 \sim 0.92)$ & $0.012^{*}$ & $1.18(0.55 \sim 0.97)$ & 0.398 \\
\hline
\end{tabular}

status, vascular invasion and UICC stage also did not significantly differ between $\mathrm{BMI}^{\text {low }}$ and $\mathrm{BMI}^{\text {high }}$ groups. It is also noteworthy that the total serum cholesterol level was significantly lower in $\mathrm{BMI}^{\text {low }}$ group compared with $\mathrm{BMI}^{\text {high }}$ group $(P$-value $=0.029)$.

\section{BMI is significantly correlated with surgical outcome after curative hepatectomy}

To clarify the association between BMI and surgical outcome, OS and RFS rates in $\mathrm{BMI}^{\text {low }}$ and $\mathrm{BMI}^{\text {high }}$ groups were analyzed. Hepatic resection procedure was performed and differential OS rates after surgical treatment between $\mathrm{BMI}^{\text {low }}$ and $\mathrm{BMI}^{\text {high }}$ groups were firstly examined. Among all 484 patients, 291 (60.1\%) patients including $173 \mathrm{BMI}^{\text {low }}$ patients and $118 \mathrm{BMI}^{\text {high }}$ patients died during follow-up period. The Kaplan-Meier OS curve of patients between the two groups is plotted (Figure 1A). The respective OS rates at the $1^{\text {st }}, 2^{\text {nd }}, 3^{\text {rd }}, 4^{\text {th }}$ and $5^{\text {th }}$ year were $79.6 \%, 68.2 \%, 55.5 \%, 50.2 \%$, and $41.1 \%$ for $\mathrm{BMI}^{\text {low }}$ group while $84.9 \%, 70.5 \%, 63.9 \%, 56.6 \%$, and $50.5 \%$ for $\mathrm{BMI}^{\text {high }}$ patients. Further analysis for cumulative survival rates indicated that OS rates were significantly lower in the

$\mathrm{BMI}^{\text {low }}$ than in the $\mathrm{BMI} \mathrm{I}^{\text {high }}$ population $(P$-value $=0.015)$.

HCC recurred in 351 patients comprising of 205

$\mathrm{BMI}^{\text {low }}$ and $146 \mathrm{BMI}^{\text {high }}$ patients. Kaplan-Meier survival curves for RFS in all patients are shown in Figure 1B. While the RFS rates at the $1^{\text {st }}, 2^{\text {nd }}, 3^{\text {rd }}, 4^{\text {th }}$ and $5^{\text {th }}$ year were $59.6 \%, 43.1 \%, 35.7 \%, 26.3 \%$, and $19 \%$ for BMI ${ }^{\text {low }}$ patients and $68.4 \%, 51 \%, 43.9 \%, 35.4 \%$, and $30.2 \%$ for BMI ${ }^{\text {high }}$ patients, respectively, it was found that the cumulative RFS rate was significantly lower in BMI ${ }^{\text {low }}$ than in $B M I^{\text {high }}$ group (log-rank test; $P$-value $=0.010$ ) suggesting that lower preoperative BMI might have advert influence for surgical prognosis after liver resection surgery.

\section{Serum cholesterol level is a potential risk factor for BMI associated surgical outcome after hepatectomy}

Potential risk factors that contributed to postoperative cancer recurrence rate after surgical resection were then examined. A univariate analysis identified a number of factors correlated with differential HCC prognosis after surgical treatment. The preferential 
Table 3: Demographic data of HCC patients clarified with different BMI and Cholesterol level.

\begin{tabular}{|c|c|c|c|c|c|}
\hline Characteristics & $\mathrm{BMI}^{\text {low }} / \mathrm{Cho}^{\text {low }}$ & $\mathrm{BMI}^{\text {low }} / \mathrm{Cho}^{\text {high }}$ & $\mathrm{BMI}^{\text {high }} / \mathrm{Cho}^{\text {low }}$ & $\mathrm{BMI}^{\text {high }} / \mathrm{Cho}^{\text {high }}$ & P-value \\
\hline Age (years) & 62.4 & 59.9 & 62.4 & 58.7 & 0.211 \\
\hline$<57$ & 57 & 11 & 38 & 18 & \\
\hline$\geq 57$ & 134 & 19 & 97 & 20 & 0.124 \\
\hline \multicolumn{6}{|l|}{ Gender } \\
\hline Male & 144 & 21 & 98 & 33 & \\
\hline Female & 47 & 9 & 37 & 5 & 0.298 \\
\hline \multicolumn{6}{|l|}{ DM status } \\
\hline Non-DM & 147 & 22 & 89 & 27 & \\
\hline DM & 44 & 8 & 46 & 11 & 0.182 \\
\hline Platelet $\left(x 10^{3}\right)$ & 157.3 & 164.9 & 141.4 & 169.8 & \multirow{2}{*}{0.106} \\
\hline$<60000$ & 18 & 1 & 5 & 1 & \\
\hline$\geq 60000$ & 173 & 29 & 130 & 37 & 0.113 \\
\hline Serum AFP ( $\mu g / L)$ & 3609.1 & 2840.3 & 1456.2 & 17471.6 & 0.12 \\
\hline$\leq 400$ & 146 & 23 & 107 & 30 & \\
\hline$>400$ & 37 & 6 & 26 & 8 & 0.997 \\
\hline Total Bilirubin (mg/dl) & 1.02 & 0.94 & 1.39 & 0.93 & 0.478 \\
\hline$<1.2$ & 140 & 24 & 96 & 28 & \\
\hline$\geq 1.2$ & 51 & 6 & 137 & 10 & 0.856 \\
\hline Albumin(mg/dl) & 3.88 & 3.9 & 3.89 & 4.12 & $0.024^{*}$ \\
\hline$<3.5$ & 30 & 5 & 24 & 3 & \\
\hline$\geq 3.5$ & 158 & 25 & 109 & 35 & 0.515 \\
\hline Sugar (mg/dl) & 106 & 112 & 122 & 109 & 0.485 \\
\hline$<126$ & 151 & 24 & 108 & 31 & \\
\hline$\geq 126$ & 31 & 6 & 25 & 7 & 0.93 \\
\hline AST (IU/L) & 60 & 58.4 & 53.5 & 44.5 & 0.291 \\
\hline$<40$ & 94 & 12 & 66 & 23 & \\
\hline$\geq 40$ & 96 & 8 & 69 & 15 & 0.4 \\
\hline TG & 82 & 128 & 100 & 142 & $<0.001^{*}$ \\
\hline$<200$ & 188 & 25 & 124 & 32 & \\
\hline$\geq 200$ & 2 & 5 & 6 & 5 & $<0.001^{*}$ \\
\hline \multicolumn{6}{|l|}{ Child stage } \\
\hline A & 148 & 20 & 109 & 34 & \\
\hline B & 24 & 5 & 15 & 2 & \\
\hline C & 2 & 0 & 0 & 0 & 0.512 \\
\hline \multicolumn{6}{|l|}{ TNM stage } \\
\hline I & 45 & 5 & 39 & 10 & \\
\hline ॥ & 75 & 14 & 55 & 20 & \\
\hline III & 31 & 4 & 25 & 6 & \\
\hline IV & 20 & 3 & 6 & 1 & 0.455 \\
\hline \multicolumn{6}{|l|}{ Differentiation } \\
\hline Well & 14 & 1 & 7 & 2 & \\
\hline Moderate & 97 & 14 & 54 & 19 & \\
\hline Poor & 58 & 10 & 61 & 16 & 0.248 \\
\hline \multicolumn{6}{|l|}{ Size $(\mathrm{cm})$} \\
\hline$<5$ & 128 & 19 & 102 & 24 & \\
\hline$\geq 5$ & 63 & 11 & 33 & 14 & 0.248 \\
\hline \multicolumn{6}{|l|}{ Number } \\
\hline Single & 157 & 27 & 115 & 31 & \\
\hline Multiple & 34 & 3 & 20 & 7 & 0.674 \\
\hline \multicolumn{6}{|l|}{ Vascular invasion } \\
\hline Positive & 118 & 16 & 78 & 23 & \\
\hline Negative & 51 & 7 & 42 & 11 & 0.854 \\
\hline
\end{tabular}

*: $P$-value $<0.05$. 
preoperative parameters for poorer survival rate in patients undergoing liver surgery included: (1) age over 57; (2) BMI < 25; (3) gender (male); (4) abnormal serum AST level; (5) hypoalbuminemia (serum albumin level $<3.5 \mathrm{mg} / \mathrm{dL}$ ); (6) hyperbilirubinemia (serum bilirubin $>1.2 \mathrm{mg} / \mathrm{dL}$ ) (7) higher serum AFP (AFP > 400mg/ dl); (8) higher Child-Pugh grading (with a Child-Pugh grade of B or C); (9) poorly differentiation; (10) higher TNM stage grading; (11) greater tumor size ( $>5 \mathrm{~cm}$ ); (12) the detection of vascular invasion and (13) multiple tumors. In contrast, by using multivariate analysis, it was found that only BMI $<25$, hypoalbuminemia, higher serum AFP level, greater TNM stage grading and poorer differentiation were potential risk contributors for HCC prognosis after surgical treatment (Table 2A). Risk factors associated with OS rates after hepatic surgical resection were also examined. A univariate analysis defined 11 identical factors to influence HCC recurrence (Table 2B) whereas the multivariate analysis revealed that BMI < 25, hypoalbuminemia, higher serum AFP level, higher
TNM stage grading and higher Child-Pugh grading (with a Child-Pugh grade of B or C) were significant factors contributing to patient survival after surgical procedure (Table 2B).

Interestingly, although the results showed that BMI $<25$ seems to be a significant contributor for OS and RFS rates; according to Cox regression analysis, DM was not a potential risk factor for HCC prognosis after surgical treatment suggesting that there might be another factor(s) to influence BMI associated surgical outcome. Based on the analysis in Table 1, significantly lower percentage of $\mathrm{DM}$ and lower serum cholesterol level were detected in $\mathrm{BMI}^{\text {low }}$ group compared to $\mathrm{BMI}^{\text {high }}$ population, implying the potential correlation between these factors and BMI mediated contribution of post-operative survival rates. By using logistic regression analysis, BMI significantly indeed correlated with serum cholesterol levels ( $P$-value $=0.029$ ) indicating that pre-operative serum cholesterol level is an important factor in predicting OS and RFS rates in HCC patients undergoing curative hepatic resection
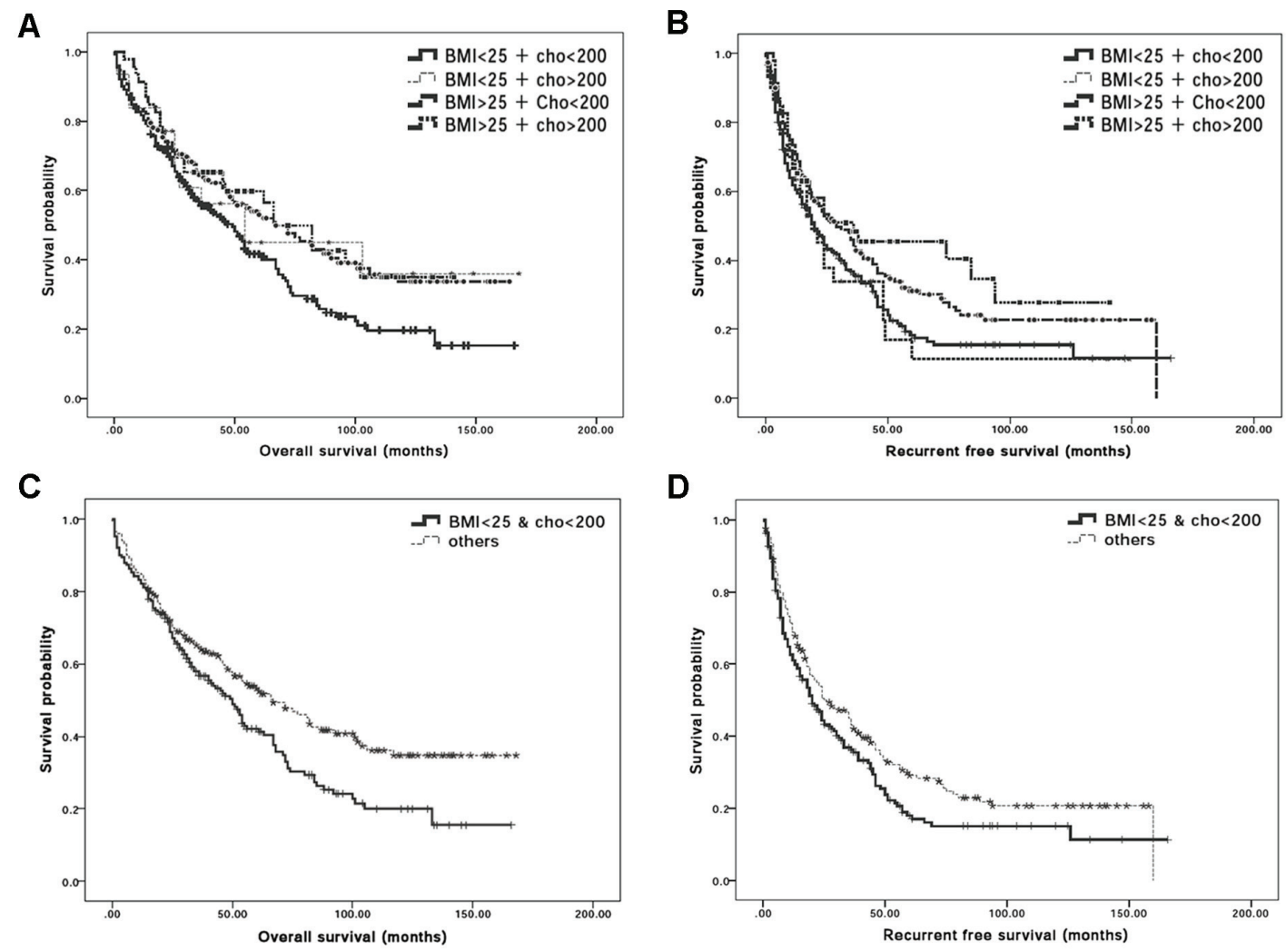

Figure 2: Synergistic effect of BMI and serum total cholesterol levels for post-operative outcomes in HCC patients. A. Post-operative Kaplan-Meier survival curves for overall survival rate of HCC patients classified based on BMI $=25 \mathrm{~kg} / \mathrm{m}^{2}$ and serum cholesterol level $=200 \mathrm{mg} / \mathrm{dl}$. The cumulative overall survival rates showed significant low overall survival rate in $\mathrm{BMI}^{\text {low }} / \mathrm{Chol}^{\text {low }} \mathrm{HCC}$ patients who received hepatectomy when compared with $\mathrm{BMI}^{\text {high }} / \mathrm{Chol}^{\text {low }} \mathrm{HCC}$ patients $(P$-value $=0.010)$. B. Post-operative Kaplan-Meier survival curves for disease survival rate of HCC patients classified based on BMI $=25 \mathrm{~kg} / \mathrm{m}^{2}$ and serum cholesterol level $=200 \mathrm{mg} / \mathrm{dl}$. The cumulative overall survival rates showed significant low disease free survival rate in $\mathrm{BMI}{ }^{\text {low }} / \mathrm{Chol}^{\text {low }}$ HCC patients who received hepatectomy when compared with $\mathrm{BMI}^{\text {high }} / \mathrm{Chol}^{\text {low }} \mathrm{HCC}$ patients $(P$-value $=0.031)$. C. Post-operative Kaplan-Meier survival curves for overall survival rate between the $\mathrm{BMI}^{\text {low/}} \mathrm{Chol}^{\text {low }} \mathrm{HCC}$ patients and remaining $\mathrm{HCC}$ patients. The cumulative overall survival rates were significantly difference between these 2 groups (log-rank test; $P$-value $=0.007$ ); D. Post-operative Kaplan-Meier survival curves for recurrence-free survival in $\mathrm{BMI}^{\text {low}} / \mathrm{Chol}^{\text {low }} \mathrm{HCC}$ patients who received hepatectomy. The cumulative recurrence-free survival rates were significantly different between the $\mathrm{BMI}^{\text {low }} / \mathrm{Chol}^{\text {low }}$ and remaining $\mathrm{HCC}$ patients $(\log$-rank test; $P$-value $=0.039)$. 
Table 4: Univariate and multivariate Cox regression analysis for (A) OS and (B) RFS rates of $\mathrm{BMI}^{\text {low }} \mathrm{Chol}^{\text {low }} \mathrm{HCC}$ patients.

\begin{tabular}{|c|c|c|c|c|}
\hline \multirow{2}{*}{ Variable } & \multicolumn{2}{|c|}{ Univariate Cox-regression } & \multicolumn{2}{|c|}{ Multivariate Cox-regression } \\
\hline & $\mathrm{HR}(95 \% \mathrm{Cl})$ & P-value & $\mathrm{HR}(95 \% \mathrm{Cl})$ & P-value \\
\hline Age (>57yrs) & $1.3(0.9 \sim 1.89)$ & 0.16 & - & - \\
\hline Gender (female) & $1.11(0.75 \sim 1.62)$ & 0.61 & - & - \\
\hline Diabetes (Y/M) & $1.04(0.71 \sim 1.53)$ & 0.82 & - & - \\
\hline Serum AST value(>40IU/L) & $1.44(1.0 \sim 2)$ & $0.032^{\star}$ & $1.35(0.95 \sim 1.94)$ & 0.097 \\
\hline Sugar(>126 mg/dl) & $1.11(0.71 \sim 1.72)$ & 0.66 & $\cdot$ & $\cdot$ \\
\hline Serum albumin $(>3.5 \mathrm{mg} / \mathrm{dl})$ & $0.5(0.33 \sim 0.78)$ & $<0.002^{\star}$ & $1.53(0.3 \sim 0.92)$ & $0.025^{*}$ \\
\hline Serum bilirubin (>1.2 mg/dl) & $1.1(0.75 \sim 1.6)$ & 0.63 & $\cdot$ & $\cdot$ \\
\hline Serum AFP value $(>400 \mathrm{ng} / \mathrm{ml})$ & $1.44(0.95 \sim 2.2)$ & 0.088 & - & - \\
\hline Child-Pugh grade ( $B$ or $C / A)$ & $1.78(1.17 \sim 2.71)$ & $0.007^{\star}$ & $1.27(0.75 \sim 2.14)$ & 0.378 \\
\hline TNM stage & $1.29(1.07 \sim 1.54)$ & $0.006^{*}$ & $1.2(0.94 \sim 1.52)$ & 0.141 \\
\hline Diff. degree (Poor) & $1.2(0.91 \sim 1.59)$ & 0.207 & $\cdot$ & - \\
\hline Tumor size $(>5 \mathrm{~cm})$ & $1.56(1.1 \sim 2.2)$ & $0.013^{\star}$ & $1.42(0.87 \sim 2.33)$ & 0.161 \\
\hline Tumor number (multiplicity) & $1.06(0.69 \sim 1.61)$ & 0.803 & - & - \\
\hline Vascular invasion $(\mathrm{N} / \mathrm{Y})$ & $0.88(0.61 \sim 1.28)$ & 0.51 & - & - \\
\hline
\end{tabular}

\begin{tabular}{|c|c|c|c|c|}
\hline \multirow{2}{*}{ Variable } & \multicolumn{2}{|c|}{ Univariate Cox-regression } & \multicolumn{2}{|c|}{ Multivariate Cox-regression } \\
\hline & $\mathrm{HR}(95 \% \mathrm{Cl})$ & P-value & $\mathrm{HR}(95 \% \mathrm{Cl})$ & P-value \\
\hline Age (>57yrs) & $1.23(0.84 \sim 1.81)$ & 0.291 & - & - \\
\hline Gender (Female) & $1.05(0.7 \sim 1.57)$ & 0.829 & - & - \\
\hline Diabetes (N/Y) & $0.75(0.49 \sim 1.16)$ & 0.198 & - & - \\
\hline Serum AST value (>40IU/L) & $1.36(0.96 \sim 1.94)$ & 0.087 & - & - \\
\hline Sugar (>126 mg/dl) & $0.82(0.5 \sim 1.34)$ & 0.429 & - & - \\
\hline Serum albumin(>3.5mg/dl) & $0.46(0.29 \sim 0.72)$ & $0.001^{*}$ & $0.6(0.33 \sim 1.09)$ & 0.094 \\
\hline Serum bilirubin (>1.2 mg/dl) & $1.34(0.91 \sim 1.98)$ & 0.142 & - & - \\
\hline Serum AFP value (>400ng/ml) & $1.85(1.21 \sim 2.83)$ & $0.005^{*}$ & $1.85(1.18 \sim 2.91)$ & $0.007^{*}$ \\
\hline Child-Pugh grade (B or $C / A)$ & $2.6(1.72 \sim 3.93)$ & $<0.001^{\star}$ & $2.24(1.32 \sim 3.78)$ & $0.003^{*}$ \\
\hline TNM stage & $1.28(1.05 \sim 1.55)$ & $0.013^{\star}$ & $1(0.78 \sim 1.29)$ & 0.976 \\
\hline Diff. degree (Poor) & $1.21(0.9 \sim 1.64)$ & 0.209 & - & - \\
\hline Tumor size $(>5 \mathrm{~cm})$ & $1.69(1.17 \sim 2.43)$ & $0.005^{*}$ & $1.73(1.05 \sim 2.84)$ & $0.032^{*}$ \\
\hline Tumor number (multiplicity) & $0.96(0.61 \sim 1.51)$ & 0.875 & - & - \\
\hline Vascular invasion $(\mathrm{N} / \mathrm{Y})$ & $1.04(0.7 \sim 1.53)$ & 0.861 & - & - \\
\hline
\end{tabular}

*: $P$-value $<0.05$.

surgery.

\section{Synergistic effect of BMI and serum total cholesterol levels for post-operative outcomes in HCC patients}

Of 484 patients who received the operations, preoperative serum cholesterol levels from 394 patients were recorded. Among them, 191, 30, 135 and 38 patients were classified into $\mathrm{BMI}^{\text {high}} / \mathrm{Chol}^{\text {high }} \mathrm{BMI}^{\text {low}} / \mathrm{Chol}^{\text {high }}$ BMI $^{\text {high }} /$ $\mathrm{Chol}^{\text {low }}$ and $\mathrm{BMI}^{\text {low }} / \mathrm{Chol}^{\text {low }}$ groups, respectively. Further analysis showed no significant differences in age, gender, the preoperative liver function and histopathological parameters including the serum total bilirubin, serum albumin, serum AFP, Child-Pugh grade, TNM stage, differentiation status, tumor size, presence of vascular invasion and number of operated tumors among 4 groups (Table 3).

To further determine whether differential cholesterol and BMI values exhibited different susceptibility for postoperative mortality and recurrence- related death, the OS and RFS rates after surgical treatment between different groups were analyzed. Among all 394 subjects, 232 (68.9\%) patients died during the follow-up, comprising of $124(64.9 \%) \mathrm{BMI}^{\text {low }} / \mathrm{Chol}^{\text {low }}, 15(50 \%) \mathrm{BMI}^{\text {low }} / \mathrm{Chol}^{\text {high }}$, 72(53.3\%) BMI ${ }^{\text {high }} / \mathrm{Chol}^{\text {low }}$ and $17(55.3 \%) \mathrm{BMI}^{\text {high }} / \mathrm{Chol}^{\text {high }}$ patients. The OS rates at the $1^{\text {st }}, 2^{\text {nd }}, 3^{\text {rd }}, 4^{\text {th }}$ and $5^{\text {th }}$ year were $82.2 \%, 68.8 \%, 56.8 \%, 50.6 \%$ and $41.5 \%$ for $\mathrm{BMI}^{\text {low }}$ Chol ${ }^{\text {low }}$ patients; $81.2 \%, 65 \%, 55.7 \%, 50.5 \%$ and $42.2 \%$

for $\mathrm{BMI}^{\mathrm{low}} / \mathrm{Chol}^{\text {high }}$ patients; $83.7 \%, 72.3 \%, 66 \%, 59.6 \%$ and $54 \%$ for $\mathrm{BMI}^{\text {high }} / \mathrm{Chol}^{\text {low }}$ patients and $88.4 \%, 68.4 \%$, $61.2 \%, 53.2 \%$ and $50.1 \%$ for $\mathrm{BMI}^{\text {high }} / \mathrm{Chol}^{\text {high }}$ patients. Kaplan-Meier curves for OS in $\mathrm{BMI}^{\mathrm{low}} / \mathrm{Chol}^{\text {low }}$ and other 3 groups indicated that the cumulative OS rates were significantly higher for $\mathrm{BMI}^{\text {high }} / \mathrm{Chol}^{\text {low }}$ patients compared with $\mathrm{BMI}^{\text {low }} / \mathrm{Chol}^{\text {low }}$ group (Figure 2A; log-rank test, $P$-value $=0.011)$. HCC recurred in 283 patients as 43 (74.8\%) of them were $\mathrm{BMI}^{\mathrm{low}} / \mathrm{Chol}^{\text {low }}, 23(79.3 \%)$ of them were $\mathrm{BMI}^{\text {low }} / \mathrm{Chol}^{\text {high }}, 94(69.6 \%)$ of them were $\mathrm{BMI}^{\text {high/ }}$ $\mathrm{Chol}^{\text {low }}$ and $23(72 \%)$ of them were $\mathrm{BMI}^{\text {high }} / \mathrm{Chol}^{\text {high }}$. The RFS rates at the $1^{\text {st }}, 2^{\text {nd }}, 3^{\text {rd }}, 4^{\text {th }}$ and $5^{\text {th }}$ year were $61 \%$, $44.4 \%, 36.2 \%, 25.4 \%$ and $18 \%$ for $\mathrm{BMI}^{\mathrm{low}} / \mathrm{Chol}^{\mathrm{low}}$ group, $58.6 \%, 36.9 \%, 29.5 \%, 22.2 \%$ and $11.1 \%$ for $\mathrm{BMI}^{\mathrm{low} /}$ $\mathrm{Chol}^{\text {high }}$ group, $71.1 \%, 53.4 \%, 45 \%, 35.4 \%$ and $30 \%$ for $\mathrm{BMI}^{\text {high }} / \mathrm{Chol}^{\text {low }}$ group and $65.2 \%, 51 \%, 44.8 \%, 34.8 \%$ and $32.2 \%$ for $\mathrm{BMI}^{\text {high }} / \mathrm{Chol}^{\text {high }}$ patients. Kaplan-Meier curves for RFS rates showed significant difference in $\mathrm{BMI}^{\text {low/ }}$ $\mathrm{Chol}^{\text {low }}$ and the other 3 groups for the cumulative RFS rates (Figure 2B; log-rank test, $P$-value $=0.032$ ). In brief, it could be concluded that in addition to liver functions and HCC tumor markers, lower BMI and lower preoperative serum cholesterol levels could also be important to determine postoperative outcomes in response to surgical procedure.

Based on previous analyses, BMI and serum total cholesterol levels could, solely or combined, predict post-operative outcomes. By using logistic Pearson's correlation analysis, BMI and serum cholesterol levels are indeed significantly correlated $(P$-value $=0.029)$. It 
therefore becomes important to further define whether $\mathrm{BMI}$ and serum cholesterol level is linked to predicate surgical outcomes in HCC patients. To this end, we determined the post-operative surgical outcomes, namely OS and RFS rates, between $\mathrm{BMI}^{\text {low }} / \mathrm{Chol}^{\text {low }}(N=191)$ and remaining subjects $(N=203)$. For $\mathrm{BMI}^{\text {low }} / \mathrm{Chol}^{\text {low }}$ group, $232(58.9 \%)$ subjects died during follow-up; the respect OS rates at the $1^{\text {st }}, 2^{\text {nd }}, 3^{\text {rd }}, 4^{\text {th }}$ and $5^{\text {th }}$ year were $82.2 \%, 68.8 \%$, $56.8 \%, 50.6 \%$ and $41.5 \%$ as the OS rates for the remaining subject groups at the $1^{\text {st }}, 2^{\text {nd }}, 3^{\text {rd }}, 4^{\text {th }}$ and $5^{\text {th }}$ year were $84.7 \%, 72.1 \%, 64.6 \%, 58.5 \%$ and $53.2 \%$, respectively. Kaplan-Meier cumulative OS curves revealed a significant difference between these two groups (Figure 2C; log-rank test, $P$-value $=0.007)$. The RFS rates also significantly differed between $\mathrm{BMI}^{\text {low }} / \mathrm{Chol}^{\text {low }}$ and the rest of subjects. $\mathrm{HCC}$ recurred in 143 patients of the $\mathrm{BMI}^{\text {low }} / \mathrm{Chol}^{\text {low }}$ group and the RFS rates at the $1^{\text {st }}, 2^{\text {nd }}, 3^{\text {rd }}, 4^{\text {th }}$ and $5^{\text {th }}$ year were $61 \%, 44.4 \%, 36.2 \%, 25.4 \%$ and $18 \%$, respectively while the RFS rates in the non BMI ${ }^{\text {low }} / \mathrm{Chol}^{\text {low }}$ patients at the $1^{\text {st }}$, $2^{\text {nd }}, 3^{\text {rd }}, 4^{\text {th }}$ and $5^{\text {th }}$ year were $68.8 \%, 50.5 \%, 43.2 \%, 34.8 \%$ and $29.1 \%$, respectively. Kaplan-Meier survival curves for RFS rates showed a significant difference between $\mathrm{BMI}^{\text {low/ }}$ $\mathrm{Chol}^{\text {low }}$ and others (Figure 2D; log-rank test, $P$-value $=$ 0.039) implying that combination of low BMI and low serum cholesterol level might have advert effects on RFS.

Potential risk factors to influence OS rate and post-operative cancer recurrence rate of $\mathrm{BMI}^{\text {low }} / \mathrm{Chol}^{\text {low }}$ group were also examined. Using univariate analysis, 10 common factors significantly associated with OS and RFS rates were identified. They included: (1) the $\mathrm{BMI}^{\text {low }}$ Chol $^{\text {low }}$ condition; (2) abnormal serum AST level; (3) hypoalbuminemia (serum albumin level $<3.5 \mathrm{mg} / \mathrm{dL}$ ); (4) higher serum AFP (AFP > 400mg/dl); (5) higher Child-Pugh grading; (6) higher TNM stage grading; and (7) greater tumor size ( $>5 \mathrm{~cm}$ ) (Table 4). By using multivariate analysis, only (1) the $\mathrm{BMI}^{\text {low }} / \mathrm{Chol}^{\text {low }}$ condition and (2) hypoalbuminemia were significantly contribute to HCC recurrence (Table 4A). On the contrary, (1) the $\mathrm{BMI}^{\text {low}} / \mathrm{Chol}^{\text {low }}$ condition; (2) higher serum AFP (AFP > 400mg/dl); (3) higher Child-Pugh grading (with a ChildPugh grade of B or C) and (4) greater tumor size ( $>5$ $\mathrm{cm}$ ) were defined as important regulator for OS rate (Table 4B).

\section{DISCUSSION}

In the present study, we conducted a retroperspective analysis for a cohort aiming to better define the role of BMI and its associated factors as $\mathrm{HCC}$ prognostic markers. The results showed that $\mathrm{HCC}$ patients with low pre-operative BMI, classified by BMI lower than $25 \mathrm{~kg} / \mathrm{m}^{2}$, exhibited lower OS and RFS rates after curative hepatic resection surgery. Further survival analysis indicated that lower preoperative serum cholesterol level in $\mathrm{BMI}^{\text {low }}$ patients could be an important contributor for poorer clinical prognosis. It is the first time, to the best of our knowledge, that a low BMI and low serum cholesterol levels were reported to contribute to poorer HCC prognosis after curative operation.

BMI has been considered an important factor in predicting the prognostic outcome in patients with colon, breast and lung cancers $[22,23]$. In a physiological aspect, it was shown that visceral fat infiltration is associated with inferior oncologic outcomes following pancreatoduodenectomy for pancreatic adenocarcinoma providing a potential obesity associated mechanism for cancer promotion $[24,25]$. In addition, high BMI has also been implicated as a risk factor for the development of postoperative complications after a variety of operations suggesting that BMI could be a useful marker to predict surgical outcome [26]. In HCC, some papers have shown that mortality and occurrence are associated with a high BMI $[8,27,28]$ and others proposed that obesity is associated with increased morbidity and mortality following major abdominal procedures [7, 29]. Furthermore, a number of papers demonstrated an association between BMI and perioperative outcomes with hepatectomy [30-36] while other studies, however, found that overweight $(\mathrm{BMI} \geq 25)$ is not a risk factor for postoperative surgical outcomes after hepatic resection in patients with primary HCC [13]. Taken together, it remains unclear whether obesity can be a prognostic factor after curative resection for primary HCC.

It was widely accepted that overweight and obese subjects could be more susceptible for higher cancer prevalence and poorer prognosis $[8,22,23]$ whilst low BMI has never been considered as a prognostic factor contributing to post-operative OS or RFS rates in patients with neoplasias. In contrast, several results found that there was higher mortality in low BMI HCC patients compared with those with high BMI, possibly due to the consequences of poorer liver metabolism status in $\mathrm{BMI}^{\text {low }}$ subjects $[13,31]$. To further clarify the controversial results between different studies, physiological data ranging from serological index, liver pathology (such as cirrhosis) to tumor states were analyzed to reveal potential underlying mechanisms. The analyses indicated that the $\mathrm{BMI}^{\text {high }}$ group had a higher total serum cholesterol value than $\mathrm{BMI}^{\text {low }}$ patients - in agreement with the fact that patients with metabolic disorders are more common in obese patients than in lean subjects [37]. Interestingly, combination of BMI and total serum cholesterol level served as a risk factor for surgical outcome but not for cancer recurrence prevalence by using Cox-regression analysis between $\mathrm{BMI}^{\text {low }} / \mathrm{Chol}^{\text {low }}$ and the rest of subjects. Nevertheless, the survival analysis showed a significantly poorer OS and RFS rates in the $\mathrm{BMI}^{\text {low }} / \mathrm{Chol}^{\text {low }}$ compared with the other subjects indicating that, in addition to liver function profile and AFP levels, tumor grade, serum cholesterol levels and BMI could be also important for determination of post-operative surgical outcome.

It is also noteworthy that the presence of DM was 
not a significant independent prognostic factor for RFS or OS rates in the current study using either univariate or multivariate analyses although a recent report concluded that obesity and DM promoted the risk of HCC [38]. Previous finding showed that insulin could induce peripheral lipolysis, hepatic accumulation of free fatty acid and production of reactive oxygen species (ROS) thereby leading to HCC development [39]. As most DM patients included in the current study were on their early disease stage and not on insulin medication, the null association between DM and RFS/OS is therefore expected.

The liver plays a central role in lipid metabolism involving the production and storage of apoproteins (Apo) and lipoproteins as well as catabolism of various lipids and excretion of cholesterol and phospholipids. An alteration in liver functions resulting from cellular injury often leads to changes in the serum concentration of cholesterol and lipoproteins. Low levels of plasma cholesterol and lipoproteins are often detected in chronic liver diseases and presented as a malnutritional and end stage liver function status. In molecular level, previous studies showed that down-regulation of acyl-transferase, a rate-limiting enzyme for lipoprotein synthesis, led to a decrease of serum triglyceride and total cholesterol levels in subjects with liver disease. In addition, an in vitro study further showed a deregulated synthesis of Apo A and/or reduced phosphatidylcholine (PC) as well as decreased levels of high-density, low-density, and very low-density lipoproteins (HDL, LDL, and VLDL, respectively). Furthermore, the blood lipids including triglycerides, total cholesterol, HDL, LDL, and VLDL, were negatively correlated with the severity of liver damage in patients with $\mathrm{HBV}$ - or HCV-mediated chronic liver dysfunction [40-42]. In addition, lower cholesterol level was correlated with severe liver fibrosis suggesting that low serum cholesterol levels could be often detected in diseased liver [40-43]. In the present study, it was found that lower total serum cholesterol level $(P$-value $=0.029)$ was detected in $\mathrm{BMI}^{\text {low }} / \mathrm{Chol}^{\text {low }}$ patients compared with the non $\mathrm{BMI}^{\text {low }}$ $\mathrm{Chol}^{\text {low }}$ subjects, indicating that higher recurrent rate and poorer OS rate in $\mathrm{BMI}^{\text {low }} / \mathrm{Chol}^{\text {low }}$ population could possibly be the consequences of imbalanced lipid metabolism, altered immune status and nutritional shortage of liver malfunction. Interestingly, no significant associations were found to correlate $\mathrm{HBV} / \mathrm{HCV}$ infection (Supplementary Figure S1), liver fibrosis (Supplementary Figure S2) and DM (Supplementary Figure S3) with OS and RFS rates for HCC patients in current cohort implying that potential determinants for surgical outcomes in HCC patients remained to be determined.

In conclusion, this study showed for the first time that a low BMI and hypocholesteronemia contributed to lower OS or RFS rates. Coexistence of low BMI and low serum cholesterol level could serve as a promising prognostic factor to predict post-operative $\mathrm{HCC}$ recurrence and OS in patients undergoing surgical hepatectomy. The poorer prognosis in $\mathrm{BMI}^{\text {low }} / \mathrm{Cho}^{\text {low }} \mathrm{HCC}$ patients undergoing hepatic resection surgery could be a consequence of poor peri-operative condition resulting from abnormal liver lipid metabolism. The finding could be of great benefit for surgeons to use pre-operative BMI and serum cholesterol levels as alternative index to achieve better surgical outcomes.

\section{MATERIALS AND METHODS}

\section{Clinical information}

Four hundred and eighty-four patients who had undergone curative hepatectomy for HCC between January 2000 and December 2010 at the Department of Gastroenterological Surgery, Ren-Ai branch, Taipei City Hospital, Taiwan were included in present study. The patients included in the present study were (i) with a good general condition with performance status test of grade 0 to 1 , (ii) diagnosed with primary $\mathrm{HCC}$, (iii) contained the tumor with a Child-Pugh classification grade of A or $\mathrm{B}$, and (iv) exhibited the solitary or multiple HCCs those were clinically resectable and no abdominal computed tomographic (CT) or magnetic resonance imaging (MRI) evident vascular invasion or distant metastasis. In contrast, the patients (i) with microscopic cancer cell persistence at the surgical margin, (ii) having received multimodality therapy for multiple HCCs, (iii) detected with distant metastasis within 3 months after the operation, and (iv) lost to follow-up were excluded. Participants' body weights and heights were recorded before surgery in the in-hospital day as BMI was defined using the formula: weight $(\mathrm{kg})$ divided by height $(\mathrm{m})$ squared. According to the World Health Organization (WHO) classification [21], all participants were initially classified into 4 groups including the subjects with BMI $<18.5,18.5<=\mathrm{BMI}$ $<25,25<=\mathrm{BMI}<30$ and $\mathrm{BMI}>=30$ and showed no significant difference for OS and RFS rates among groups, except between groups of BMI $<18.5$ and $\mathrm{BMI}>=30$ (Supplementary Figure S4). In addition, relative less cases of extreme BMI groups $(N=17$ for $\mathrm{BMI}<18.5$ and $N$ $=36$ for $\mathrm{BMI}>=30)$ and previous findings showing that overweight $(25<=\mathrm{BMI}<30)$ and obese $(\mathrm{BMI}>$ $=30$ ) patients displayed similar postoperative outcome [44-46]; we therefore decided to divided all subjects into 2 groups of $\mathrm{BMI}<25$ and $>25$ as $\mathrm{BMI}^{\text {low }}$ and $\mathrm{BMI}^{\text {high }}$, respectively. Further analysis according to the guideline from Laboratory Department, Taipei City hospital, Ren-Ai branch was also carried out. The patients were classified into four groups: $\mathrm{BMI}^{\text {high}} / \mathrm{Chol}^{\text {high }} \mathrm{BMI}^{\text {low }} / \mathrm{Chol}^{\text {high }}, \mathrm{BMI}^{\text {high} /}$ $\mathrm{Chol}^{\text {low }}$ and $\mathrm{BMI}^{\text {low }} / \mathrm{Chol}^{\text {low }}$ using 25 of BMI and $200 \mathrm{mg} /$ dl of serum cholesterol as cut-off values. The clinical data such as age, gender, blood glucose level, hepatitis infection, platelets count, serological alpha-fetoprotein 
(AFP) level, albumin, aspartate aminotransferase (AST), total bilirubin, total cholesterol, triglyceride and tumor tissue score, based on size, number, Child/TNM stage, differentiation status and vascular invasion were recorded. Postoperative mortality was defined as deaths within 30 days post-surgery as postoperative morbidity was defined as any complication requiring intervention during the perioperative hospitalization.

All patients included in this study were confirmed for $\mathrm{HCC}$ diagnosis based on pathological examination and evaluation for their serological hepatitis viral titer, liver function/cirrhosis and tumor characteristics by CT pre- and post-operatively. The hepatic reserve was defined using platelet count and Child-Pugh classification [47] as patients' immunological states were assessed by the absolute counts of peripheral blood leukocytes and lymphocytes [48-50]. Routine blood tests were performed on the day of admission and 7 days postoperatively. Tumorous parameters including tumor morphology and extent, serum alpha-fetoprotein levels, and portal vein thrombosis was classified based on the Union Internationale Contrele Cancer (UICC) classification [51, 52]. Patients were subjected to monthly follow-up physical examinations after operation while blood samples were collected to monitor serum AFP level at every re-visits. In addition, serial CT or liver ultrasonography was also performed every 3 to 6 months at re-visits to examine any possible recurrence.

\section{Statistical analysis}

All statistical analyses were performed using SPSS 17.0 (SPSS, Inc. Chicago, IL, USA). The differential clinicopathological variables between the $\mathrm{BMI}^{\text {low }}$ and $\mathrm{BMI}^{\text {high }}$ groups were compared. The continuous variables are expressed as the mean \pm standard deviation and comparisons were made using student's $t$-test as categorical variables were compared using chi-square tests. The OS and RFS rates were estimated by the Kaplan-Meier analysis and the differences in survival rate between groups were determined using the log rank test. The significant variables were analyzed in univariate and multivariate analysis using Cox's proportional hazard model while Cox regression was adopted for multivariate analysis of prognostic predictors. A $p$-value $<0.05$ was considered to be significant.

\section{ACKNOWLEDGMENTS}

Authors would also like to thank Mr Chang-Yi Chen and Ms Wan-Jung Chang for data stratification as well as Mrs Courtney Anne Curtis and Dr Jude Clapper (Taipei American School) for critical review and English corrections for the manuscript.

\section{CONFLICTS OF INTEREST}

The authors declare no conflict of interest

\section{GRANT SUPPORT}

This work is supported by grant 102TPECH05 from the Taipei City Hospital/Department of Health, Taipei City Government as well as the grant Most-103-2314-B010-024-MY3 from Ministry of Science and Technology, Taiwan.

\section{REFERENCES}

1. Parkin DM, Bray F, Ferlay J and Pisani P. Estimating the world cancer burden: Globocan 2000. International journal of cancer. 2001; 94:153-156.

2. Yamashita Y, Taketomi A, Itoh S, Kitagawa D, Kayashima H, Harimoto N, Tsujita E, Kuroda Y and Maehara Y. Longterm favorable results of limited hepatic resections for patients with hepatocellular carcinoma: 20 years of experience. Journal of the American College of Surgeons. 2007; 205:19-26.

3. Itoh S, Morita K, Ueda S, Sugimachi K, Yamashita Y, Gion T, Fukuzawa K, Wakasugi K, Taketomi A and Maehara Y. Long-term results of hepatic resection combined with intraoperative local ablation therapy for patients with multinodular hepatocellular carcinomas. Annals of surgical oncology. 2009; 16:3299-3307.

4. Hashimoto K, Ikeda Y, Korenaga D, Tanoue K, Hamatake M, Kawasaki K, Yamaoka T, Iwatani Y, Akazawa K and Takenaka K. The impact of preoperative serum C-reactive protein on the prognosis of patients with hepatocellular carcinoma. Cancer. 2005; 103:1856-1864.

5. Calle EE, Rodriguez C, Walker-Thurmond $\mathrm{K}$ and Thun MJ. Overweight, obesity, and mortality from cancer in a prospectively studied cohort of U.S. adults. The New England journal of medicine. 2003; 348:1625-1638.

6. Obesity: preventing and managing the global epidemic. Report of a WHO consultation. World Health Organization technical report series. 2000; 894:i-xii, 1-253.

7. Flancbaum L and Choban PS. Surgical implications of obesity. Annual review of medicine. 1998; 49:215-234.

8. Caldwell SH, Crespo DM, Kang HS and Al-Osaimi AM. Obesity and hepatocellular carcinoma. Gastroenterology. 2004; 127(5 Suppl 1):S97-103.

9. Tanaka S, Iimuro Y, Hirano T, Hai S, Suzumura K, Nakamura I, Kondo Y and Fujimoto J. Safety of hepatic resection for hepatocellular carcinoma in obese patients with cirrhosis. Surgery today. 2013; 43:1290-1297.

10. Nishikawa H, Osaki Y, Takeda H, Sakamoto A, Saito S, Nishijima N, Nasu A, Arimoto A, Kita R and Kimura T. Effect of body mass index on survival after curative therapy for non-B non-C hepatocellular carcinoma. JGLD. 2013; 
22:173-181.

11. Singal AK, Kamath PS, Francisco Ziller N, DiCecco S, Shoreibah M, Kremers W, Charlton MR, Heimbach JK, Watt KD and Shah VH. Nutritional status of patients with alcoholic cirrhosis undergoing liver transplantation: time trends and impact on survival. Transplant international. 2013; 26:788-794.

12. Nishikawa H, Arimoto A, Wakasa T, Kita R, Kimura T and Osaki Y. The Relation between Obesity and Survival after Surgical Resection of Hepatitis C Virus-Related Hepatocellular Carcinoma. Gastroenterology research and practice. 2013; 2013:430438.

13. Mullen JT, Davenport DL, Hutter MM, Hosokawa PW, Henderson WG, Khuri SF and Moorman DW. Impact of body mass index on perioperative outcomes in patients undergoing major intra-abdominal cancer surgery. Annals of surgical oncology. 2008; 15:2164-2172.

14. Goodwin PJ, Ennis M, Pritchard KI, Trudeau ME, Koo J, Madarnas Y, Hartwick W, Hoffman B and Hood N. Fasting insulin and outcome in early-stage breast cancer: results of a prospective cohort study. Journal of clinical oncology. 2002; 20:42-51

15. Wang XJ, Yuan SL, Lu Q, Lu YR, Zhang J, Liu Y and Wang WD. Potential involvement of leptin in carcinogenesis of hepatocellular carcinoma. WJG. 2004; 10:2478-2481.

16. Lorincz AM and Sukumar S. Molecular links between obesity and breast cancer. Endocrine-related cancer. 2006; 13:279-292.

17. Chlebowski RT, Aiello E and McTiernan A. Weight loss in breast cancer patient management. Journal of clinical oncology. 2002; 20:1128-1143.

18. Wang Q, Lau WY, Zhang B, Zhang Z, Huang Z, Luo $\mathrm{H}$ and Chen $\mathrm{X}$. Preoperative total cholesterol predicts postoperative outcomes after partial hepatectomy in patients with chronic hepatitis B- or C-related hepatocellular carcinoma. Surgery. 2014; 155:263-270.

19. Giovannini I, Chiarla C, Giuliante F, Vellone M, Ardito $\mathrm{F}$ and Nuzzo G. The relationship between albumin, other plasma proteins and variables, and age in the acute phase response after liver resection in man. Amino acids. 2006; 31:463-469.

20. Shin DY, Kim KJ, Cho Y, Park KH, Hwang S, Chung WY and Lee EJ. Body Mass Index Is Associated with Hypercholesterolemia following Thyroid Hormone Withdrawal in Thyroidectomized Patients. International journal of endocrinology. 2014; 2014:649016.

21. Health implications of obesity. National Institutes of Health Consensus Development Conference Statement. Annals of internal medicine. 1985; 103(6 ( Pt 2)):1073-1077.

22. Boyd NF, Campbell JE, Germanson T, Thomson DB, Sutherland DJ and Meakin JW. Body weight and prognosis in breast cancer. Journal of the National Cancer Institute.
1981; 67:785-789.

23. Dhar DK, Kubota H, Tachibana M, Kotoh T, Tabara H, Masunaga R, Kohno H and Nagasue N. Body mass index determines the success of lymph node dissection and predicts the outcome of gastric carcinoma patients. Oncology. 2000; 59:18-23.

24. Mathur A, Hernandez J, Shaheen F, Shroff M, Dahal S, Morton C, Farrior T, Kedar R and Rosemurgy A. Preoperative computed tomography measurements of pancreatic steatosis and visceral fat: prognostic markers for dissemination and lethality of pancreatic adenocarcinoma. HPB. 2011; 13:404-410.

25. Mathur A, Zyromski NJ, Pitt HA, Al-Azzawi H, Walker JJ, Saxena R and Lillemoe KD. Pancreatic steatosis promotes dissemination and lethality of pancreatic cancer. Journal of the American College of Surgeons. 2009; 208:989-994; discussion 994-986.

26. Merkow RP, Bilimoria KY, McCarter MD and Bentrem DJ. Effect of body mass index on short-term outcomes after colectomy for cancer. Journal of the American College of Surgeons. 2009; 208:53-61.

27. Akiyama T, Mizuta T, Kawazoe S, Eguchi Y, Kawaguchi Y, Takahashi H, Ozaki I and Fujimoto K. Body mass index is associated with age-at-onset of HCV-infected hepatocellular carcinoma patients. WJG. 2011; 17:914-921.

28. Muto Y, Sato S, Watanabe A, Moriwaki H, Suzuki K, Kato A, Kato M, Nakamura T, Higuchi K, Nishiguchi S, Kumada H, Ohashi Y and Long-Term Survival Study G. Overweight and obesity increase the risk for liver cancer in patients with liver cirrhosis and long-term oral supplementation with branched-chain amino acid granules inhibits liver carcinogenesis in heavier patients with liver cirrhosis. Hepatology research. 2006; 35:204-214.

29. Choban PS and Flancbaum L. The impact of obesity on surgical outcomes: a review. Journal of the American College of Surgeons. 1997; 185:593-603.

30. Mathur AK, Ghaferi AA, Osborne NH, Pawlik TM, Campbell DA, Englesbe MJ and Welling TH. Body mass index and adverse perioperative outcomes following hepatic resection. Journal of gastrointestinal surgery. 2010; 14:1285-1291.

31. Mathur AK, Ghaferi AA, Sell K, Sonnenday CJ, Englesbe $\mathrm{MJ}$ and Welling TH. Influence of body mass index on complications and oncologic outcomes following hepatectomy for malignancy. Journal of gastrointestinal surgery. 2010; 14:849-857.

32. Utsunomiya T, Okamoto M, Kameyama T, Matsuyama A, Yamamoto M, Fujiwara M, Mori M, Aimitsu S and Ishida T. Impact of obesity on the surgical outcome following repeat hepatic resection in Japanese patients with recurrent hepatocellular carcinoma. WJG. 2008; 14:1553-1558.

33. Ishizuka M, Kubota K, Kita J, Shimoda M, Kato M and Sawada T. Underweight patients show an increased rate 
of postoperative death after surgery for hepatocellular carcinoma. Journal of surgical oncology. 2011; 104:809813.

34. Okamura Y, Maeda A, Matsunaga K, Kanemoto H and Uesaka K. Negative impact of low body mass index on surgical outcomes after hepatectomy for hepatocellular carcinoma. Journal of hepato-biliary-pancreatic sciences. 2012; 19:449-457.

35. Itoh S, Ikeda Y, Kawanaka H, Okuyama T, Kawasaki K, Eguchi D, Korenaga D and Takenaka K. The effect of overweight status on the short-term and 20-y outcomes after hepatic resection in patients with hepatocellular carcinoma. The Journal of surgical research. 2012; 178:640-645.

36. Mathur A, Franco ES, Leone JP, Osman-Mohamed H, Rojas H, Kemmer N, Neff GW, Rosemurgy AS and Alsina AE. Obesity portends increased morbidity and earlier recurrence following liver transplantation for hepatocellular carcinoma. HPB. 2013; 15:504-510.

37. Dindo D, Muller MK, Weber M and Clavien PA. Obesity in general elective surgery. Lancet. 2003; 361:2032-2035.

38. Jiang M, Liu F, Xiong WJ, Zhong L, Xu W, Xu F and Liu YB. Combined MELD and blood lipid level in evaluating the prognosis of decompensated cirrhosis. WJG. 2010; 16:1397-1401.

39. Eriksson JW. Metabolic stress in insulin's target cells leads to ROS accumulation - a hypothetical common pathway causing insulin resistance. FEBS Lett. 2007; 581: 37343742.

40. Patel K, Thompson AJ, Chuang WL, Lee CM, Peng CY, Shanmuganathan G, Thongsawat S, Tanwandee T, Mahachai V, Pramoolsinsap C, Cho M, Han KH, Shah SR, Foster GR, Clark PJ, Pulkstenis E, et al. Insulin resistance is independently associated with significant hepatic fibrosis in Asian chronic hepatitis $\mathrm{C}$ genotype 2 or 3 patients. Journal of gastroenterology and hepatology. 2011;26:1182-1188.

41. Hsu CS, Liu CH, Liu CJ, Hsu SJ, Chen CL, Hwang JJ, Lai MY, Chen PJ, Chen DS and Kao JH. Association of metabolic profiles with hepatic fibrosis in chronic hepatitis C patients with genotype 1 or 2 infection. Journal of gastroenterology and hepatology. 2010; 25:970-977.

42. Zheng RD, Xu CR, Jiang L, Dou AX, Zhou K and Lu LG. Predictors of hepatic steatosis in HBeAg-negative chronic hepatitis B patients and their diagnostic values in hepatic fibrosis. International journal of medical sciences. 2010; 7:272-277.

43. Vere CC, Streba CT, Streba L and Rogoveanu I. Lipid serum profile in patients with viral liver cirrhosis. Medical principles and practice. 2012; 21:566-568.

44. Cucchetti A, Cescon M, Ercolani G, Di Gioia P, Peri E and Pinna AD. Safety of hepatic resection in overweight and obese patients with cirrhosis. The British journal of surgery. 2011; 98:1147-1154.

45. Tanaka S, Iimuro Y, Hirano T, Hai S, Suzumura K, Nakamura I, Kondo Y and Fujimoto J. Safety of hepatic resection for hepatocellular carcinoma in obese patients with cirrhosis. Surgery Today. 2013; 43:1290-1297.

46. Nishikawa H, Osaki Y, Takeda H, Sakamoto A, Saito S, Nishijima N, Nasu A, Arimoto A, Kita R and Kimura T. Effect of body mass index on survival after curative therapy for non-B non-C hepatocellular carcinoma. Journal of Gastrointestinal and Liver Diseases. 2013; 22:173-181.

47. Pugh RN, Murray-Lyon IM, Dawson JL, Pietroni MC and Williams R. Transection of the oesophagus for bleeding oesophageal varices. The British journal of surgery. 1973; 60:646-649.

48. Ogawa K, Hirai M, Katsube T, Murayama M, Hamaguchi K, Shimakawa T, Naritake Y, Hosokawa T and Kajiwara T. Suppression of cellular immunity by surgical stress. Surgery. 2000; 127:329-336.

49. Mukherjee M and Sahasrabuddhe MB. Effect of operation on peripheral lymphocyte counts and production of adenosine triphosphate (ATP) in cancer patients. Journal of surgical oncology. 1982; 20:1-8.

50. Roth JA, Golub SH, Grimm EA, Eilber FR and Morton DL. Effects of operation on immune response in cancer patients: sequential evaluation of in vitro lymphocyte function. Surgery. 1976; 79:46-51.

51. Wittekind C, Compton CC, Greene FL and Sobin LH. TNM residual tumor classification revisited. Cancer. 2002; 94:2511-2516.

52. A new prognostic system for hepatocellular carcinoma: a retrospective study of 435 patients: the Cancer of the Liver Italian Program (CLIP) investigators. Hepatology. 1998; 28:751-755. 